\title{
CALLUS FORMATION AND PLANT REGENERATION FROM PROTOPLASTS OF SUNFLOWER CALLI AND HYPOCOTYLS
}

\author{
Conceição Santos, Gustavo Caldeira \\ Department of Biology, University of Aveiro, \\ 3800 Aveiro, Portugal
}

(Received: February 18, 1997. Accepted: November 11, 1997)

\begin{abstract}
Sunflower (cv. Girapac SH222) protoplasts were obtained from 4-7 day-old hypocotyls and cotyledons and from two-month old calli. Higher yields of protoplasts were achieved with medium $\mathrm{E} 1\left(\mathrm{KCl} 25 \mathrm{~g} \cdot \mathrm{dm}^{-3}, \mathrm{CaCl}_{2} 2 \mathrm{~g} \cdot \mathrm{dm}^{-3}\right.$, MES $0.7 \mathrm{~g} \cdot \mathrm{dm}^{-3}, \mathrm{pH} 5.5$ ) and the combination of Driselase Fluka $0.2 \%$, Macerozyme Onozuka $0.2 \%$ and Cellulase Onozuka R10 $0.2 \%$. Hypocotyls gave the highest yields of protoplasts, followed by cotyledons and calli. Protoplasts were cultivated in liquid and on solid media using both L4M (Burrus et al., 1991) and V-KM (Bokelman and Roest, 1983) media. Culture on solid M1 medium (L4M medium supplemented with NAA $3.0 \mathrm{mg} \cdot \mathrm{dm}^{-3}, 2,4-\mathrm{D} 0.1 \mathrm{mg} \cdot \mathrm{dm}^{-3}$ and BA $1.0 \mathrm{mg} \cdot \mathrm{dm}^{-3}$ ) gave a good planting efficiency with the development of many white-green colonies. These colonies gave rise to small calli which were transferred to MSmod medium (MS medium supplemented with $\mathrm{KCl} 5 \mathrm{~g} \cdot \mathrm{dm}^{-3}$, and polyvinylpyrrolidone (PVP, $4 \mathrm{~g} \cdot \mathrm{dm}^{-3}$ ) containing benziladenine (BA, $0.5 \mathrm{mg} \cdot \mathrm{dm}^{-3}$ ), naphtaleneacetic acid (NAA, $\left.0.5 \mathrm{mg} \cdot \mathrm{dm}^{-3}\right)$ and giberelic acid $\left(\mathrm{GA} 30.1 \mathrm{mg} \cdot \mathrm{dm}^{-3}\right)$. After two weeks, calli were transferred to MSmod medium containing BA $1.0 \mathrm{mg} \cdot \mathrm{dm}^{-3}$, NAA $0.1 \mathrm{mg} \cdot \mathrm{dm}^{-3}$, and $\mathrm{GA}_{3} 0.1 \mathrm{mg} \cdot \mathrm{dm}^{-3}$ for shoot formation. Shoots were excised and induced to root in MSmod supplemented with BA $0.1 \mathrm{mg} \cdot \mathrm{dm}^{-3}$, NAA $1.0 \mathrm{mg} \cdot \mathrm{dm}^{-3}$, and $\mathrm{GA}_{3} 0.1 \mathrm{mg} \cdot \mathrm{dm}^{-3}$. Plantlets were then transferred to sterilised vermiculite for greenhouse acclimation.
\end{abstract}

KEY WORDS: Helianthus annuus, protoplast, plant regeneration.

\section{INTRODUCTION}

Genetic improvement of sunflower has been a constant necessity due to the importance of this crop in oil and food industry. Protoplasts are essential for breeding techniques involving somatic hybridisation and direct transformation involving either traditional genotypes and new cell lines obtained by somaclonal variation. Sunflower protoplasts have been isolated previously from different organs such as hypocotyls (Chanabe et al., 1991; Burrus et al., 1991), leaves (Guilley and Hahne, 1989; Samaj et al., 1994) and cotyledons (Bohorova et al., 1986, Samaj et al., 1994) or stem (Samaj et al., 1994). However, successful isolation from callus has not been reported yet in this species. Nevertheless, callus can be used for selection of tolerant cells to physical stresses (Santos and Caldeira, 1995, 1997), and these variant cells can be used, later, as a source for hybridisation or transformation.

Regeneration of plants from sunflower protoplasts is a very difficult task. Chanabe et al. (1991) succeeded in regeneration of plants from $H$. petiolaris protoplasts and, later, Burrus et al. (1991) reported the regeneration of fertile plants from $\mathrm{cv}$. Pionneer PT024.

From literature, two assumptions may be made for regeneration of plants from protoplasts in sunflower: 1) solid me- dium is better for cell division (Burrus et al., 1991; Chanabe et al., 1991; Alibert, Chanabe and Burrus, 1994), and 2) protoplast yield and division and plant regeneration is extremely dependent on genotypes (Chanabe et al., 1991; Alibert et al., 1994). Even in the same genotype and with the same laboratory conditions it may be observed great variability of division frequencies between experiments (Guilley and Hahne, 1989).

We describe here a simple and efficient method for routine callus formation from calli protoplasts and for plant regeneration from hypocotyl protoplasts of a sunflower commercial cultivar Girapac SH222.

\section{MATERIALS AND METHODS}

\section{Plant material}

Seeds of Helianthus annuus cv. Girapac SH 222 were obtained from SCLEPAL (Portugal). Seeds were soaked for 812 hours and surface sterilised in $20 \%$ commercial bleach for $30 \mathrm{~min}$., followed by six changes of sterile water. Seeds were germinated on MS1/2 medium (Murashige and Skoog, 1962) lacking phytohormones and with $1 \%$ sucrose, $0.7 \% \mathrm{w} / \mathrm{v}$ Phytagel and $\mathrm{pH}$ 5.7. Cultures were kept in a 16 hour day light cycle at $73 \mu \mathrm{Em}^{-2} \mathrm{~s}^{-1}$. 


\section{Initiation and maintenance of callus culture}

In vitro cultures were initiated from young cotyledons and maintained in MSmod medium (MS medium supplemented with $\mathrm{KNO}_{3} 5 \mathrm{~g} \cdot \mathrm{dm}^{-3}$, PVP $4 \%$, BA $0.5 \mathrm{mg} \cdot \mathrm{dm}^{-3}$, NAA $0.5 \mathrm{mg} \cdot \mathrm{dm}^{-3}$, and $\mathrm{GA}=0.1 \mathrm{mg} \cdot \mathrm{dm}^{-3}$. Cultures were sub-cultured at 3 week intervals and kept in a light/dark cycle $\left(16 / 8 \mathrm{~h}, 53 \mu \mathrm{Em}^{-2} \mathrm{~s}^{-1}\right)$ at $23 \pm 1^{\circ} \mathrm{C}$.

\section{Protoplast isolation}

Two month-old calli, cotyledons and hypocotyls fragments from 3-7 day-old plantlets were incubated overnight at $26^{\circ} \mathrm{C}$, using four different digestion media (E1, E2, E3 and E4) according to the following table (Table 1):

TABLE 1. Composition of the different enzymatic solutions used in the isolation of protoplasts from cotyledons, hypocotyls and calli of Helianthus annuus cv. Girapac SH 222.

\begin{tabular}{|c|c|c|c|c|}
\hline Media & E1 & E2 & E3 & E4 \\
\hline Cellulase R10 (\%) & 0.2 & 0.2 & 0.5 & 0.50 \\
\hline Macerozyme R10 (\%) & 0.2 & 0.2 & 0.02 & 0.02 \\
\hline Driselase $(\%)$ & 0.2 & 0.2 & 0.02 & 0.02 \\
\hline $\mathrm{KCl}\left(\mathrm{g} \cdot \mathrm{dm}^{-3}\right)$ & 25.0 & - & 25.0 & - \\
\hline $\mathrm{CaCl}_{2}\left(\mathrm{~g} \cdot \mathrm{dm}^{-3}\right)$ & 2.0 & - & 2.0 & - \\
\hline $\operatorname{MES}\left(\mathrm{g} \cdot \mathrm{dm}^{-3}\right)$ & 0.7 & - & 0.7 & - \\
\hline Manitol (M) & - & 0.6 & - & 0.6 \\
\hline $\mathrm{pH}$ & 5.5 & 5.5 & 5.5 & 5.5 \\
\hline \multicolumn{5}{|l|}{$\mathrm{mOsmKg}^{-1}$} \\
\hline hypocot and cotyledon & $500 \pm 10$ & $500 \pm 10$ & $500 \pm 10$ & $500 \pm 10$ \\
\hline calli & $620 \pm 10$ & $620 \pm 10$ & $620 \pm 10$ & $620 \pm 10$ \\
\hline
\end{tabular}

In all media osmolality was adjusted to $620 \mathrm{mOsm} \cdot \mathrm{Kg}^{-1}$ for calli and $500 \mathrm{mOsm} \cdot \mathrm{Kg}^{-1}$ for hypocotyls and cotyledons (Table I). The digested tissue was gently shaken to release the protoplasts and filtered through a nylon sieve $(100 \mu \mathrm{m}$ pore size). The filtrate was centrifuged at $75 \mathrm{xg}$. Cell debris were removed by centrifuging protoplasts in salt or manitol solution containing 12\% Ficoll for $15 \mathrm{~min}$. at 250xg (Burrus at al., 1991). Floated protoplasts were washed by two other centrifugations in S medium (Burrus et al. 1991) and diluted to a final density of $10 \times 10^{4}$ protoplasts per $\mathrm{cm}^{3}$ in $\mathrm{L} 4 \mathrm{M}$ medium (Burrus et al., 1991) or V-KM medium (Bokelman and Roest, 1983).

\section{Culture in liquid medium}

Protoplasts were diluted to different densities $\left(2,5 \times 10^{4}\right.$ and $5 \times 10^{4}$ protoplasts per $\left.\mathrm{cm}^{3}\right)$ in Petri dishes $(60 \times 15 \mathrm{~mm})$ containing $3 \mathrm{~cm}^{3}$ of liquid medium. Four different media were tested: M1 (L4M medium supplemented with NAA $3.0 \mathrm{mg} \cdot \mathrm{dm}^{-3}$, 2,4-D $0.1 \mathrm{mg} \cdot \mathrm{dm}^{-3}$ and BA $1.0 \mathrm{mg} \cdot \mathrm{m}^{-3}$ ); $\mathbf{M} 2$ (L4M medium supplemented with NAA $0.1 \mathrm{mg} \cdot \mathrm{dm}^{-3}$, and BA $2.2 \mathrm{mg} \cdot \mathrm{dm}^{-3}$ ); M3 (V-KM medium supplemented with NAA $3.0 \mathrm{mg} \cdot \mathrm{dm}^{-3}$, 2,4-D $0.1 \mathrm{mg} \cdot \mathrm{dm}^{-3}$ and BA $1.0 \mathrm{mg} \cdot \mathrm{dm}^{-3}$ ); M4 (V-KM medium supplemented with NAA $0.1 \mathrm{mg} \cdot \mathrm{dm}^{-3}$ and BA 2.2 $\mathrm{mg} \cdot \mathrm{dm}^{-3}$ ). Protoplasts were incubated at $23^{\circ} \mathrm{C}$ in the dark. After seven days of culture, cultures were diluted with the sa- me media but with reduced osmolality $\left(350 \mathrm{mOsm} \cdot \mathrm{Kg}^{-1}\right)$ and reduced NAA concentration $\left(0.1 \mathrm{mg} \cdot \mathrm{dm}^{3}\right)$.

\section{Culture on solid medium}

Protoplasts were mixed, to final densities of $5 \times 10^{4}$ protoplasts per $\mathrm{cm}^{3}$ and $2,5 \times 10^{4}$ protoplasts per $\mathrm{cm}^{3}$, with $0,6 \%$ $(\mathrm{w} / \mathrm{v})$ low gelling agarose (Sigma) melted either in L4M or $\mathrm{V}$-KM media. Twenty droplets of $0,25 \mathrm{~cm}^{3}$ were dispensed in Petri dishes $(100 \times 15 \mathrm{~mm})$, allowed to solidify and surrounded by, respectively, L4M (Burrus et al., 1991) or V-KM liquid media $\left(5 \mathrm{~cm}^{3} / \mathrm{dish}\right)$. Protoplasts were incubated in dark for 2 days at $23^{\circ} \mathrm{C}$. After seven days of culture, protoplasts were transferred to light. Every 8 days, $2.5 \mathrm{~cm}^{3}$ of old surrounding medium was replaced by $2.5 \mathrm{~cm}^{3}$ of new medium with reduced osmolality $\left(350 \mathrm{mOsm} \cdot \mathrm{Kg}^{-1}\right)$ and reduced NAA (0.1 $\left.\mathrm{mg} \cdot \mathrm{dm}^{-3}\right)$. Microcalli regenerated from protoplasts were transferred to MSmod medium containing BA $0.5 \mathrm{mg} \cdot \mathrm{dm}^{-3}$, NAA $0.5 \mathrm{mg} \cdot \mathrm{dm}^{-3}$, and $\mathrm{GA}_{3} 0.1 \mathrm{mg} \cdot \mathrm{dm}^{-3}$, for growth. After two weeks, calli were transferred to MSmod medium containing BA $0.5 \mathrm{mg} \cdot \mathrm{dm}^{-3}$, NAA $0.5 \mathrm{mg} \cdot \mathrm{dm}^{-3}$, and $\mathrm{GA}_{3} 0.1$ $\mathrm{mg} \cdot \mathrm{dm}^{-3}$ for shoot formation. Shoots were excised and induced to root in MSmod supplemented with BA $0.5 \mathrm{mg} \cdot \mathrm{dm}^{-3}$, NAA $0.5 \mathrm{mg} \cdot \mathrm{dm}^{-3}$, and $\mathrm{GA}_{3} 0.1 \mathrm{mg} \cdot \mathrm{dm}^{-3}$. Rooted plants were potted in vermiculite and adapted to greenhouse.

\section{RESULTS AND DISCUSSION}

\section{Isolation of protoplasts}

We evaluated the capacity of different organs (hypocotyls and cotyledons) and callus for their maximum yield of protoplast, using two different enzymatic combinations (Cellulase Onozuka R10, Macerozyme Onozuka R10 and Driselase Fluka) and osmotica ( $\mathrm{KCl}$ and $\mathrm{CaCl}_{2}$ or manitol) (Table 2). The di-

TABLE 2. Protoplast yields from hypocotyls, cotyledons and calli of Helianthus annuus cv. Girapac SH222 after 12 hours of digestion in different enzymatic solutions (values are expressed in $\times 10^{5}$ protoplasts per gram of fresh weight).

\begin{tabular}{|l|c|c|c|c|}
\hline \multirow{2}{*}{ Tissue } & \multicolumn{4}{|c|}{ Yield of prot $\left(\times 10^{5} / \mathrm{gfw}\right)$} \\
\cline { 2 - 5 } & E1 & E2 & E3 & E4 \\
\hline cotyledons & 6.6 & 1.6 & 1.2 & 0.7 \\
\hline hypocotyls & 9.8 & 4.8 & 1.8 & 1.3 \\
\hline callus & 3.2 & 0.9 & 0.9 & 0.4 \\
\hline
\end{tabular}

gestion medium El (Cellulase R10 0.2\%, Macerozyme R10 $0.2 \%$, Driselase $0.2 \%, \mathrm{KCl} 25 \mathrm{~g} \cdot \mathrm{dm}^{-3}, \mathrm{CaCl}_{2} 2 \mathrm{~g} \cdot \mathrm{dm}^{-3}$ and MES $0.7 \mathrm{~g} \cdot \mathrm{dm}^{-3}$ ) gave the best yields in all tissues. Some authors have already observed that adjusting osmolality of the enzyme mixture with mineral salts instead of manitol markedly improved protoplasts yield in sunflower (Chanabe, Burrus and Alibert, 1989; Burrus et al., 1991). Comparison of different enzymatic combinations showed that the mixtures used is this report and by other authors (Lenee and Chupeau, 1986; Bohorova, Cocking and Power, 1989) were more efficient than other enzymes (Cellulase Sigma, Pectolyase Sigma, or 
TABLE 3. Comparative rates of cell division (expressed in \%) and colony formation (expressed in \%) from protoplasts isolated from hypocotyls. cotyledons and calli of Helianthus annuus cv. Girapac SH222 in different media. (SM: solid medium; LM: liquid medium).

\begin{tabular}{|c|c|c|c|c|c|c|c|c|c|c|}
\hline \multirow[t]{2}{*}{$\begin{array}{l}\text { Tissue } \\
\text { origin }\end{array}$} & & \multicolumn{4}{|c|}{$\begin{array}{l}\text { Number (\%) of protoplasts that } \\
\text { suffered at least one divission }\end{array}$} & \multicolumn{5}{|c|}{$\begin{array}{l}\text { Number }(\%) \text { of colonies with more than } \\
\qquad 8 \text { cells }\end{array}$} \\
\hline & & M1 & M2 & M3 & M4 & & M1 & M2 & M3 & M4 \\
\hline \multirow[t]{2}{*}{ Hypocotyl } & SM: & 39 & 23 & 17 & 0.08 & SM: & 22 & 9 & 2 & 0.5 \\
\hline & LM: & 41 & 40 & 2 & 0.1 & LM: & 10 & 13 & 0.5 & $<0.01$ \\
\hline \multirow[t]{2}{*}{ cotyledon } & SM: & 55 & 9 & 4 & $<0.01$ & SM: & 7 & 2 & 0.06 & $<0.01$ \\
\hline & LM: & 43 & 0.1 & $<0.01$ & 0.05 & LM: & 15 & $<0.01$ & $<0.01$ & $<0.01$ \\
\hline \multirow[t]{2}{*}{ callus } & SM: & 13 & 0.5 & 2 & 0.01 & SM: & 5 & 0.03 & 0.08 & $<0.01$ \\
\hline & LM & 5 & $<0.0$ & $<0.01$ & $<0.01$ & LM: & 0.6 & $<0.01$ & $<0.01$ & $<0.01$ \\
\hline
\end{tabular}

only Macerozyme and Cellulase Onozuka) used previously by Santos and Caldeira (1993). Hypocotyls were the best source of protoplasts followed by cotyledons and calli (Fig. 1.1). Protoplasts from seedling material have been reported to give higher and more stable plating efficiencies than leaves (Lenee and Chupeau, 1986). Also, protoplasts from hypocotyls gave the best rates of cell division and colony formation (Figs 1.2, 1.4 and 1.5), while only few colonies were observed in cotyledon and calli protoplasts (Table 3). Protoplasts from calli frequently enlarged and developed evaginated structures (Fig. 1.3). Some authors have also described cell divisions only in hypocotyl derived protoplasts (Dupuis et al., 1990; Lenee and Chupeau, 1986; Moyene et al., 1988). On the other hand, Chanabe et al., (1989) reported the division at low frequency of cotyledon protoplasts, and Fisher and Hahne (1992) described colony formation from cotyledon protoplasts. Using the cultivar Girapac SH222, and using the method described in this report, we have achieved colony formation in all types of protoplasts. To our knowledge this is the first report of successful cell division and microcalli formation from sunflower calli protoplasts. Although with low rates of cell division, calli must be regarded as important sources of protoplasts, with particular interest when dealing with calli stably adapted to physical stresses such as salt and osmotic stress (Santos and Caldeira, 1995).

Good rates of cell division and colony formation were only obtained with the density of $5 \times 10^{4}$ protoplasts per $\mathrm{cm}^{3}$. Sustained growth and microcalli formation was only achieved in M1 medium (L4M medium supplemented with NAA 3.0 $\mathrm{mg} \cdot \mathrm{dm}^{-3}, 2,4-\mathrm{D} 0.1 \mathrm{mg} \cdot \mathrm{dm}^{-3}$ and BA $1.0 \mathrm{mg} \cdot \mathrm{dm}^{-3}$ ) (Fig. 1.4). Most of the cells growing in M3 and M4 media (both media have the composition of V-KM medium) became brown and died after some weeks. In M3 and M4 media only hypocotyl derived protoplasts regenerated into colonies, although without reproducibility.

Embedding protoplasts in agarose increased colony formation by more than $50 \%$ fold (M1) compared with protoplasts cultured in liquid medium. Colonies formed in both solid and liquid systems were unorganised and friable. Colony formation in solidified medium was slower but more colonies originated calli. Burrus et al. (1991) reported the lack of callus formation in liquid medium but in Helianthus annuus cv. Girapac $\mathrm{SH} 222$ we found that it is possible to regenerate calli in both culture systems. Cell division and calli formation seem highly dependent on the presence of 2,4-D in combination with NAA and BA. Similar needs for 2,4-D, NAA and BA have already been reported for other sunflower genotypes (Burrus et al., 1991; Samaj et al., 1994).

By 5-7 weeks colonies were transferred to MSmod medium (MS medium containing $\mathrm{KCl} 5 \mathrm{~g} \cdot \mathrm{dm}^{-3}$, PVP $4 \mathrm{~g} \cdot \mathrm{dm}^{-3}$ and supplemented with BA $0.5 \mathrm{mg} \cdot \mathrm{dm}^{-3}$, NAA $0.5 \mathrm{mg} \cdot \mathrm{dm}^{-3}$, and $\mathrm{GA}_{3} 0.1 \mathrm{mg} \cdot \mathrm{dm}^{-3}$ ). Colonies from hypocotyls, cotyledons and calli protoplasts originated microcalli. However, the number of microcalli regenerated from cotyledons and calli protoplasts was low and with great variability between experiments. Microcalli derived from hypocotyl and callus protoplasts became green and sustained growth on MSmod. However, calli derived from cotyledon protoplasts became brown and died 1 to 2 weeks after incubation in MSmod medium. This fact indicates that the origin of protoplasts is crucial not only during the first weeks of protoplast culture as stated by other authors (Lenee and Chupeau, 1986; Guilley and Hahne, 1989) but also in later stages of regeneration. Calli derived from hypocotyl protoplasts were transferred to MSmod medium supplemented with BA $1.0 \mathrm{mg} \cdot \mathrm{dm}^{-3}$, NAA $0.1 \mathrm{mg} \cdot \mathrm{dm}^{-3}$, and $\mathrm{GA}_{3} 0.1 \mathrm{mg} \cdot \mathrm{dm}^{-3}$. (Fig. 1.7). These calli regenerated structures which we identified as shoots (Fig. 1.7) by optical microscopy. In fact these structures did not present the typical individuality and bipolar organisation of embryoids. Although most authors refer the regeneration of sunflower protoplasts by embryogenesis (Dupuis et al., 1988; 1990; Moyene et al., 1988; Chanabe et al., 1991; Kransnyanky and Menczel, 1993), Bohorova, Cocking and Power (1986) described the regeneration of plants from sunflower protoplasts by organogenesis using MS medium supplemented with NAA and BA. These authors state that NAA abd BA are important for stimulating callus formation and organogenesis (Bohorova, Cocking and Power (1986). Also, protoplasts from Helianthus tuberosus originated calli with roots (Binding et al., 1981).

Up to this moment, no shoot formation was observed on calli originated from callus protoplasts. Root formation was achieved on MSmod medium supplemented with BA 0.1 $\mathrm{mg} \cdot \mathrm{dm}^{-3}$, NAA $1.0 \mathrm{mg} \cdot \mathrm{dm}^{-3}$, and $\mathrm{GA}_{3} 0.1 \mathrm{mg} \cdot \mathrm{dm}^{-3}$. Most of the plants regenerated from protoplasts were etiolated, with small leaves (Fig. 1.9) and some of them showed premature flowering and vitrification. Vitrification is a physiological disorder that affects numerous genotypes of Helianthus in vitro (Burrus et al., 1991; Chraibi et al., 1992; Santos and Caldeira, 1997). Also premature flowering is a frequent problem in sunflower (Paterson, 1984; Greco et al., 1984; Lupi et al., 1987; 

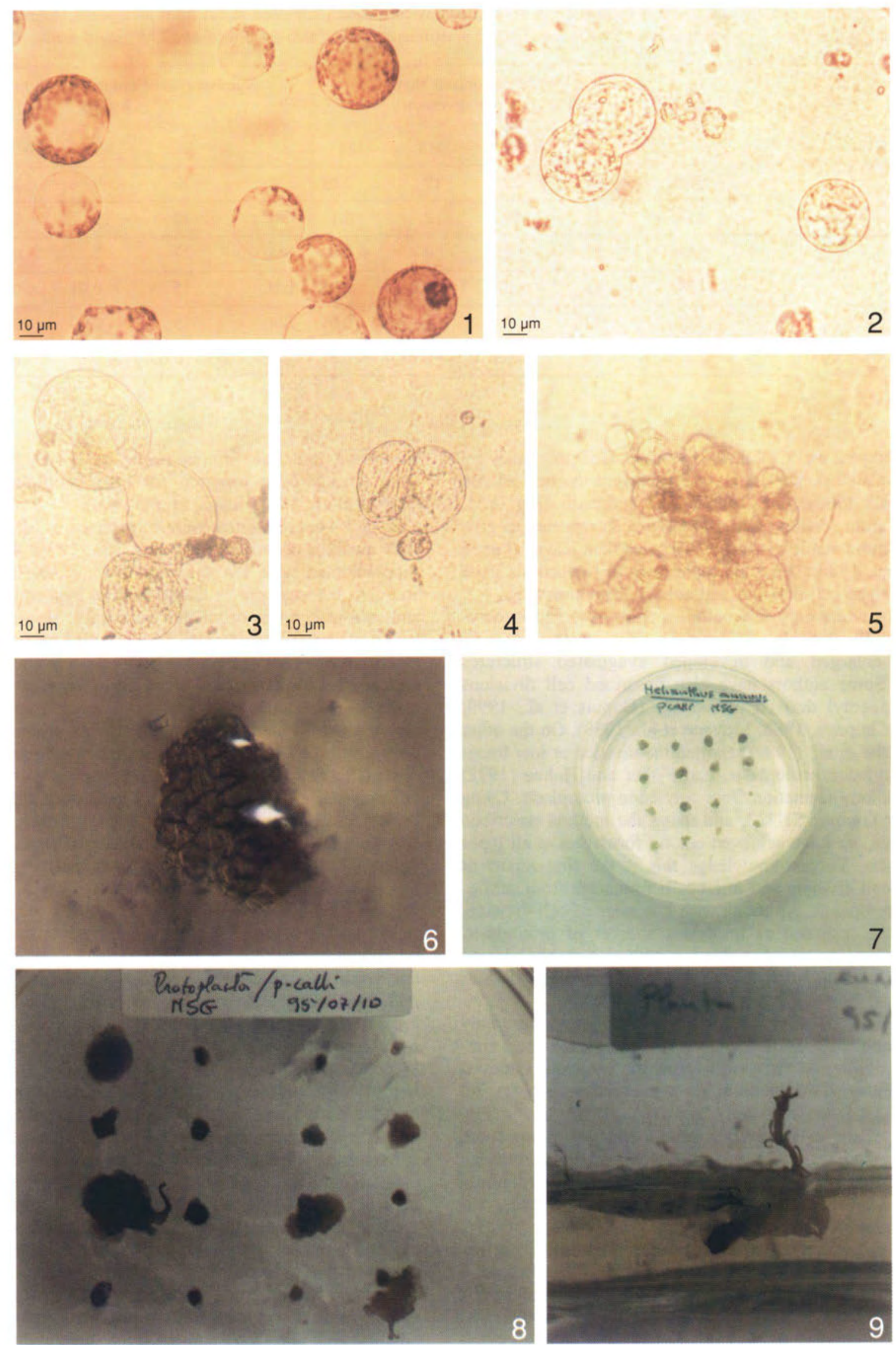

Fig. 1. Plant regeneration from Helianthus annuus cv. Girapac SH222 protoplasts: 1) freshly isolated hypocotyl derived protoplasts; 2) protoplast first division; 3) evagination; 4) protoplast derived second division; 5) colony of cells derived from protoplasts; 6) microcallus derived from protoplasts; 7) calli derived from protoplasts; 8) shoot emerging from callus; 9) rooting of shoot. 
Knittel et al., 1990; Santos and Caldeira, 1997). To reduce flowering in vitro, Wirtzens et al. (1988) suggested the addition of phenolic glycosides, while Lupi et al. (1987) suggested the use of Nitsch medium supplemented with IBA or the addition of $\mathrm{GA}_{3}$ to $\mathrm{MS}$ medium.

The protocol we report here is easy and efficient for plant regeneration from hypocotyls of sunflower while calli protoplasts divide forming calli. This is the first report of plant regeneration from protoplasts of Helianthus annuus cv. Girapac SH222 and of callus formation from callus protoplasts. Studies are undertaken to reach the regeneration of plants from callus protoplasts.

\section{LITERATURE CITED}

AliberT G., CHANABE C. and BURRUS M., 1994. Sunflower tissue and cell cultures and their use in biotechnology. Plant Physiol. Biochem 32 (1): 31-44.

BINDING H., NEHLS R., KOCK R., FINGER J. and MORDHORST G., 1981. Comparative studies on protoplast regeneration in herhaceous species of dicotiledoneae class. Z. Pflanzenphysiol. 101: 119-130.

BOHOROVA N., COCKING E. and POWER J., 1986. Isolation, culture and callus regeneration of protoplasts of wild and cultivated Helianthus species. Plant Cell Rep. 5: 256-258.

BOKELMAN G. and ROEST S., 1983. Plant regeneration from protoplasts of potato (Solanum tuberosum cv. Bintje). Z. Pflanzphysiol. 109: 259-265.

BURRUS M., CHANABE C., ALIBERT G. and BIDNEY D., 1991. Plant regeneration of fertile plants from protoplasts of sunflower (Helianthus annuus). Plant Cell Rep. 10: 161-166.

CHANABE C., BURRUS M. and ALIBERT G., 1986. Factors affecting the improvement of colony formation from sunflower protoplasts. Plant Sci. 64: 125-132.

CHANABE C., BURRUS M., BIDNEY D. and ALIBERT G., 1991. Studies of plant regeneration from protoplasts in the genus $\mathrm{He}$ lianthus. Plant Cell Rep. 9: 635-638.

CHRAIBI K.M., CASTELlE J., LATCHE A., ROUSTAN J. \& FALLOT, 1992. Regeneration potential by liquid medium culture from mature cotyledons of sunflower (Helianthus annuus). Plant Cell Rep. 10: 617-620.

DUPUIS J., GOMIERO M., PLANTEVIN, C. and CHAGVARDIEFF P., 1988. Differentiation de formes embryoides issues de protoplastes de tournesol (Helianthus annuus L.) C. R. Acad. Sci. Paris 307 (III): 465-468.
FISHER C. and HAHNE G., 1992. Structural analysis of colonies derived from sunflower (Helianthus annuus) protoplasts cultured in liquid and semi-solid media. Protoplasma 169: 130-138.

GRECO B., TANZARELlA O., GARROZZO G. \& BLANCO A.. 1984. Callus induction and shoot regeneration in sunflower $(\mathrm{He}$ lianthus annuus L.). Plant Sci. Lett. 36: 73-77.

GUILLEY E. and HAHNE G., 1989. Callus formation from isolated sunflower mesophyll protoplasts. Plant Sci. Lett. 36: 72-77.

KNITTEL N., ESCANDÓN A. and HAHNE G., 1991. Plant regeneration at high frequency from mature sunflower cotyledons. Plant Sci. 73: 219-226.

KRANSNYANSKY, and MENCZEL, 1993. Somatic embryogenesis and plant regeneration from hypocotyl protoplasts of sunflower (Helianthus annuus). Plant Cell Rep. 12 260-263.

LENNEE P. and CHUPEAU Y., 1986. Isolation and culture of sunflower protoplasts (Helianthus annuus): Factors influencing the viability of cell colonies derived from protoplasts. Plant Sci. 43: 69-75.

LUPI M. C., BENNICI A., LOCCI F. and GENNAI D., 1987. Plantlet formation from callus and shoot tip culture of Helianthus annuus (L.). Plant Cell Tissue and Org. Culture 11: 47-55.

MOYENE A., THOR V., PELISSIER D., BERGOUNIOUX C. and FREYSSINET G., 1988. Callus and embryoid formation from protoplasts of Helianthus annuus. Plant Cell Rep. 7: 97-100.

MURASHIGE T. and SKOOG F., 1962. A revised medium for growth and rapid assays with tobacco tissue cultures Physiol. Plant 15: 473-497.

PATERSON K., 1984. Shoot tip culture of Helianthus - Flowering and development of adventitious and multiple shoots. Amer. J. Bot. 71: 925-931.

SAMAJ J., OKOLOT A., BOBAK M. and GLEBA, 1994. Increase of callus and embrioid production from hypocotyl protoplasts of sunflower (Helianthus annuus) by culture in microdrops. Biol. Plant. 36 (2) 183-190.

SANTOS C. and CALDEIRA G., 1993. Isolamento e cultura de protoplastos de Helianthus annuus. Livro de Resumos das Jorn. De Estrutura Metabol. e Desenv. das Plantas, Porto, Portugal.

SANTOS C. and CALDEIRA G., 1995. Ultrastructural study of a sunflower callus line tolerant to $300 \mathrm{mM} \mathrm{NaCl}$ obtained by somaclonal variation. XXX Reunião Anual da Sociedade Portuguesa de Microscopia Electrónica e Biologia Celular, Portugal.

SANTOS C. and CALDEIRA G., 1997. Study of growth conditions for routine callus culture and in vitro plant regeneration of four Helianthus genotypes. P. Acta Bot. (in press).

WITRZENS B., SCOWCROFT W. R., DOWNES R. W and LARKIN P. J., 1988. Tissue culture and plant regeneration from sunflower (Helianthus annuus) and interspecific hybrids $(H$ tuberosus $x \mathrm{H}$. annuus) Plant Cell Tissue \& Org. Culture 13: 61-76. 


\author{
POWSTAWANIE KALUSA A REGENERACJA ROŚLIN \\ Z PROTOPLASTÓW KALUSA SŁONECZNIKA I HYPOKOTYLI
}

\title{
STRESZCZENIE
}

Protoplasty słonecznika (cv. Girapac SH222) uzyskiwano z 4-7 dniowych hypokotyli i liścieni oraz z dwumiesięcznych kalusów. Większą wydajność protoplastów uzyskiwano stosując roztwór trawiący El $\left(\mathrm{KCl} \mathrm{g} \cdot \mathrm{dm}^{-3}, \mathrm{CaCl}_{2} 2 \mathrm{~g} \cdot \mathrm{dm}^{-3}\right.$, MES $\left.0,7 \mathrm{~g} \cdot \mathrm{dm}^{-3}, \mathrm{pH} 5,5\right)$ zawierający $0,2 \%$ Driselase (Fluka), $0,2 \%$ macerazę R10 (Ozonuka) i 0,2\% celulazę R10 (Ozonuka). Największą ilość protoplastów uzyskiwano z hypokotyli, następnie z liścieni i kalusów. Protoplasty hodowano na pożywkach płynnych i stałych, w obu przypadkach stosując pożywki L4M (Burrus et al. 1991) i V-KM (Bokelman i Roest, 1993).

Kultury na stałej pożywce M1 (pożywka L4M uzupełniona o NAA $3,0 \mathrm{mg} \cdot \mathrm{dm}^{-3}, 2,4-\mathrm{D} 0,1 \mathrm{mg} \cdot \mathrm{dm}^{-3}$ i BA $1,0 \mathrm{mg} \cdot \mathrm{dm}^{-3}$ ) dały dobrą efektywność wysiewu z rozwojem licznych białozielonych kolonii. Kolonie te zapoczątkowały rozwój drobnych kalusów, które przenoszono do pożywki Msmod (pożywka MS uzupełniona $\mathrm{o} \mathrm{KCl} 5 \mathrm{~g} \cdot \mathrm{dm}^{-3}$ oraz poliwinylopirolidynę (PVP, $4 \mathrm{~g} \cdot \mathrm{dm}^{-3}$ ) zawierającej benzyloadeninę (BA, $\left.0,5 \mathrm{mg} \cdot \mathrm{dm}^{-3}\right)$, kwas naftalenooctowy (NAA, $\left.0,5 \mathrm{mg} \cdot \mathrm{dm}-3\right)$ i kwas giberelinowy $\left(\mathrm{GA}_{3}, 0,1 \mathrm{mg} \cdot \mathrm{dm}^{-3}\right)$. Po dwóch tygodniach kalusy przenoszono do pożywki Msmod zawierającej $1,0 \mathrm{mg} \cdot \mathrm{dm}^{-3} \mathrm{BA}, 1,0 \mathrm{mg} \cdot \mathrm{dm}^{-3}$ NAA i $1,0 \mathrm{mg} \cdot \mathrm{dm}^{-3} \mathrm{GA}_{3}$ w celu tworzenia pędów. Pędy odcinano i indukowano ukorzenianie w pożywce Msmod uzupełnionej o $1,0 \mathrm{mg} \cdot \mathrm{dm}^{-3} \mathrm{BA}, 1,0 \mathrm{mg} \cdot \mathrm{dm}^{-3} \mathrm{NAA}$ oraz $1,0 \mathrm{mg} \cdot \mathrm{dm}^{-3} \mathrm{GA}_{3}$. Następnie rośliny przenoszono do szklarni.

SŁOWA KLUCZOWE: Helianthus annuus, protoplast, regeracja roślin. 